\title{
Stable carbon isotope biogeochemistry of lakes along a trophic gradient
}

\author{
A. de Kluijver ${ }^{1}$, P. L. Schoon ${ }^{2}$, J. A. Downing ${ }^{3}$, S. Schouten ${ }^{2,4}$, and J. J. Middelburg ${ }^{1,4}$ \\ ${ }^{1}$ Department of Ecosystems Studies, NIOZ Royal Netherlands Institute for Sea Research, Yerseke, the Netherlands \\ ${ }^{2}$ Department of Marine Organic Biogeochemistry, NIOZ Royal Netherlands Institute for Sea Research, \\ Den Burg, the Netherlands \\ ${ }^{3}$ Department of Ecology, Evolution, and Organismal Biology, Iowa State University, Ames, IA, USA \\ ${ }^{4}$ Utrecht University, Faculty of Geosciences, Utrecht, the Netherlands \\ Correspondence to: A. de Kluijver(anna.dekluijver@deltares.nl)
}

Received: 6 April 2014 - Published in Biogeosciences Discuss.: 7 May 2014

Revised: 5 October 2014 - Accepted: 9 October 2014 - Published: 20 November 2014

\begin{abstract}
The stable carbon (C) isotope variability of dissolved inorganic and organic C (DIC and DOC), particulate organic carbon (POC), glucose and polar-lipid derived fatty acids (PLFAs) was studied in a survey of 22 North American oligotrophic to eutrophic lakes. The $\delta^{13} \mathrm{C}$ of different PLFAs were used as proxy for phytoplankton producers and bacterial consumers. Lake $p \mathrm{CO}_{2}$ was primarily determined by autochthonous production (phytoplankton biomass), especially in eutrophic lakes, and governed the $\delta^{13} \mathrm{C}$ of DIC. All organic-carbon pools showed overall higher isotopic variability in eutrophic lakes $(n=11)$ compared to oligomesotrophic lakes $(n=11)$ because of the high variability in $\delta^{13} \mathrm{C}$ at the base of the food web (both autochthonous and allochthonous carbon). Phytoplankton $\delta^{13} \mathrm{C}$ was negatively related to lake $p \mathrm{CO}_{2}$ over all lakes and positively related to phytoplankton biomass in eutrophic lakes, which was also reflected in a large range in photosynthetic isotope fractionation $\left(\varepsilon_{\mathrm{CO}_{2}}\right.$-phyto, $8-25 \%$ ). The carbon isotope ratio of allochthonous carbon in oligo-mesotrophic lakes was rather constant, while it varied in eutrophic lakes because of maize cultivation in the watershed.
\end{abstract}

\section{Introduction}

Studies suggest that lakes contribute significantly to the global carbon budget via organic matter burial and emission of $\mathrm{CO}_{2}$ to the atmosphere (Cole et al., 2007). The balance between primary production and external organic carbon input on the one hand and respiration and burial of organic carbon on the other governs whether individual lakes are sources or sinks of $\mathrm{CO}_{2}$. This metabolic balance can be disturbed by changes in nutrient or organic matter inputs to the lake. Primary (autochthonous) production increases with increasing nutrient concentrations and lakes with high autochthonous carbon production, i.e. eutrophic lakes, may be sinks for $\mathrm{CO}_{2}$ (Schindler et al., 1997). The loading of allochthonous (terrestrial) carbon is a key factor controlling community respiration of lakes. The metabolic balance of lakes is directly influenced by allochthonous organic carbon loading and trophic state (Del Giorgio and Peters, 1994; Hanson et al., 2003).

Stable carbon isotope analysis is a powerful tool for studying carbon cycling in lakes since it allows study of inorganic and organic carbon pools and changes therein. It can provide information on the metabolic balance and the sources of organic matter fuelling respiration. Respiration yields ${ }^{13} \mathrm{C}$ depleted carbon dioxide from organic matter with the result that $\delta^{13} \mathrm{C}$ of dissolved inorganic carbon (DIC) of the lakes becomes lower (Parker et al., 2010). Primary producers preferentially incorporate ${ }^{12} \mathrm{C}$ in their organic matter with the consequence that the remaining pool of DIC will be enriched in ${ }^{13} \mathrm{C}$ (Herczeg, 1987; Parker et al., 2010). The $\delta^{13} \mathrm{C}$ of the DIC pool thus integrates the relative importance of respiration and primary production (Parker et al., 2010). The $\delta^{13} \mathrm{C}$ of organic carbon pools is primarily governed by the $\delta^{13} \mathrm{C}$ of the DIC used by primary producers and the isotope fractionation during carbon fixation. Terrestrial plants use atmospheric carbon dioxide while aquatic primary producers 
Table 1. Limnological characteristics of the sampled lakes. $p \mathrm{CO}_{2}$ was determined from temperature, DIC, and $\mathrm{pH}$. $\mathrm{C}_{\mathrm{phyto}}$ is the average of chl $a$ and fatty acid based phytoplankton biomass. $\mathrm{C}_{\mathrm{bac}}$ is fatty acid derived bacteria carbon biomass. I, Iowa; M, Minnesota; TN, total nitrogen; TP, total phosphorus.

\begin{tabular}{|c|c|c|c|c|c|c|c|c|c|c|c|c|c|c|}
\hline Name & US state & Trophic state & $\begin{array}{r}\text { Temperature } \\
\left({ }^{\circ}\right)\end{array}$ & $\mathrm{pH}$ & $\begin{array}{r}\text { Alkalinity } \\
\left(\mathrm{mmol} \mathrm{L}^{-1}\right)\end{array}$ & $\begin{array}{r}\text { DIC } \\
\left(\mathrm{mmol} \mathrm{L}^{-1}\right)\end{array}$ & $\begin{array}{l}p \mathrm{CO}_{2} \\
(\mu \mathrm{atm})\end{array}$ & $\begin{array}{r}\mathrm{TN} \\
\left(\mathrm{mg} \mathrm{L}^{-1}\right)\end{array}$ & $\begin{array}{r}\mathrm{TP} \\
\left(\mu \mathrm{gL}^{-1}\right)\end{array}$ & $\begin{array}{r}\text { Chl } a \\
\left(\mu \mathrm{L} \mathrm{L}^{-1}\right)\end{array}$ & $\begin{array}{r}\text { DOC } \\
\left(\mathrm{mg} \mathrm{L}^{-1}\right)\end{array}$ & $\begin{array}{r}\text { POC } \\
\left(\mathrm{mg} \mathrm{L}^{-1}\right)\end{array}$ & $\begin{array}{r}\mathrm{C}_{\text {phyto }} \\
\left(\mathrm{mg} \mathrm{L}^{-1}\right)\end{array}$ & $\begin{array}{r}\mathrm{C}_{\mathrm{bac}} \\
\left(\mathrm{mg} \mathrm{L}^{-1}\right)\end{array}$ \\
\hline Beaver & I & $\mathrm{Eu}$ & 24.1 & 9.5 & 1.03 & 1.70 & 30 & 1.69 & 152.8 & 72.6 & 2.10 & 5.07 & 2.26 & 0.251 \\
\hline Beeds & I & $\mathrm{Eu}$ & 23.8 & 8.5 & 2.28 & 4.15 & 835 & 9.32 & 36.1 & 9.1 & 0.97 & 0.93 & 0.38 & 0.023 \\
\hline Big Creek & I & $\mathrm{Eu}$ & 25.0 & 8.5 & 1.97 & 3.89 & 795 & 6.12 & 21.3 & 8.0 & 1.56 & 1.30 & 0.32 & 0.047 \\
\hline Coralville & I & $\mathrm{Eu}$ & 24.2 & 7.8 & 2.37 & 4.55 & 4545 & 6.50 & 207.1 & 10.9 & 1.16 & 1.91 & 0.49 & 0.074 \\
\hline Little Splithand & M & $\mathrm{Eu}$ & 19.2 & 8.2 & 1.04 & 1.69 & 635 & 0.01 & 29.5 & 19.5 & 3.70 & 2.07 & 0.58 & 0.026 \\
\hline Lower Pine & I & $\mathrm{Eu}$ & 24.1 & 8.6 & 1.44 & 2.51 & 400 & 4.15 & 128.3 & 60.2 & 1.46 & 4.00 & 2.32 & 0.213 \\
\hline McBride & I & $\mathrm{Eu}$ & 22.0 & 8.8 & 1.18 & 1.98 & 195 & 1.27 & 67.9 & 42.6 & 1.71 & 2.84 & 1.80 & 0.103 \\
\hline Meyers & I & $\mathrm{Eu}$ & 27.1 & 9.8 & 1.08 & 1.49 & 10 & 2.14 & 208.7 & 86.2 & 2.70 & 9.91 & 3.65 & 0.190 \\
\hline Rodgers Park & I & $\mathrm{Eu}$ & 24.6 & 8.4 & 1.82 & 3.34 & 855 & 6.81 & 50.6 & 5.4 & 1.20 & 0.68 & 0.23 & 0.038 \\
\hline Saylorville & I & $\mathrm{Eu}$ & 25.3 & 8.5 & 2.05 & 4.03 & 830 & 4.90 & 116.3 & 23.0 & 1.80 & 1.30 & 0.96 & 0.165 \\
\hline Three Mile & I & $\mathrm{Eu}$ & 21.3 & 9.1 & 0.98 & 1.69 & 80 & 1.00 & 44.9 & 37.8 & 1.90 & 2.66 & 1.48 & 0.122 \\
\hline Beaver & M & O-M & 19.7 & 6.9 & 0.09 & 0.09 & 520 & 0.12 & 16.2 & 3.6 & 4.34 & 1.50 & 0.13 & 0.017 \\
\hline Brush Shanty & M & O-M & 20.3 & 7.4 & 0.28 & 0.29 & 655 & 0.34 & 10 & 1.4 & 4.75 & 0.56 & 0.06 & 0.014 \\
\hline Hatch & M & O-M & 20.3 & 8.4 & 1.81 & 3.04 & 735 & 0.55 & 1.9 & 0.8 & 2.08 & 0.30 & 0.04 & 0.008 \\
\hline Horsehead & M & O-M & 19.9 & 6.7 & 0.07 & 0.06 & 460 & 0.09 & 6.9 & 1.8 & 2.91 & 2.11 & 0.09 & 0.033 \\
\hline Kelly & M & O-M & 20.2 & 6.9 & 0.08 & 0.05 & 310 & 0.01 & 8.9 & 2.6 & 2.50 & 1.22 & 0.09 & 0.017 \\
\hline Leighton & M & O-M & 19.4 & 8.4 & 1.84 & 2.99 & 715 & 0.49 & 8.1 & 2.4 & 2.62 & 0.67 & 0.07 & 0.007 \\
\hline Little Sand & M & O-M & 22.8 & 8.2 & 0.75 & 1.88 & 745 & 0.19 & 11.9 & 4.9 & 3.68 & 1.24 & 0.17 & 0.023 \\
\hline O'Leary & M & O-M & 19.2 & 6.7 & 0.09 & 0.08 & 655 & 0.44 & 13.8 & 2.6 & 3.18 & 2.28 & 0.10 & 0.029 \\
\hline Sand Lake & M & O-M & 19.9 & 7.7 & 1.18 & 0.61 & 710 & 0.66 & 20.4 & 3.1 & 3.81 & 0.85 & 0.12 & 0.016 \\
\hline South Sturgeon & M & O-M & 18.6 & 6.1 & 0.22 & 0.20 & 3200 & 0.03 & 14.4 & 3.6 & 6.71 & 0.55 & 0.11 & 0.005 \\
\hline Thirty & M & O-M & 22.0 & 7.1 & 0.13 & 0.12 & 525 & 0.10 & 15.7 & 6.3 & 3.65 & 3.02 & 0.23 & 0.066 \\
\hline
\end{tabular}
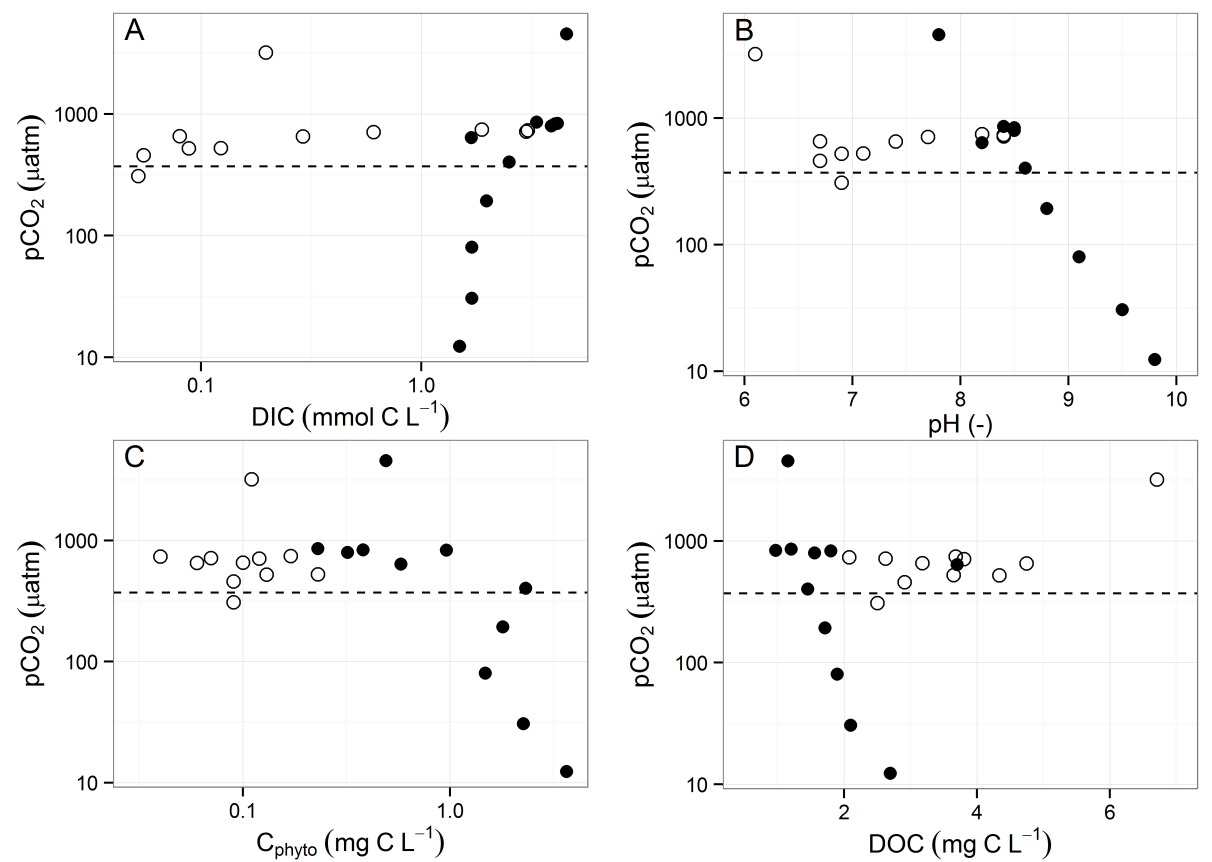

Figure 1. The relation of $\mathrm{pCO}_{2}$ in eutrophic lakes (filled circles, $n=11$ ) and oligo-mesotrophic lakes (open circles, $n=11$ ) to (a) DIC; (b) $\mathrm{pH}$; (c) $\mathrm{C}_{\text {phyto }}$; (d) DOC. The dashed line indicates atmospheric $p \mathrm{CO}_{2}(385 \mu \mathrm{atm})$.

utilize dissolved carbon dioxide or bicarbonate (Fry, 2006). The $\delta^{13} \mathrm{C}$ of terrestrially derived organic carbon is therefore often distinct from that of organic matter produced within the lakes and this difference can be used to trace carbon flows and origins in plankton food webs.

A major challenge in stable isotope studies is to elucidate the isotopic composition of microbial organisms (Middelburg, 2014), such as phytoplankton and bacteria, since it is difficult to separate these potential carbon sources from bulk particulate organic carbon (POC). Therefore, most studies use indirect methods to determine $\delta^{13} \mathrm{C}$ of phytoplankton $\left(\delta^{13} \mathrm{C}_{\text {phyto }}\right)$, bacteria $\left(\delta^{13} \mathrm{C}_{\mathrm{bac}}\right)$ and allochthonous carbon $\left(\delta^{13} \mathrm{C}_{\text {allo }}\right)$. Common methods for determining $\delta^{13} \mathrm{C}_{\text {phyto }}$ are the use of the $\delta^{13} \mathrm{C}$ of POC with correction for nonphytoplankton carbon and estimates based on $\delta^{13} \mathrm{C}$ of DIC with an isotope fractionation factor $(\varepsilon)$, obtained from 
experimental studies. Other methods are the use of zooplankton consumers as a proxy for $\delta^{13} \mathrm{C}_{\text {phyto }}$ or size fractionation of organic matter and subsequent determination of $\delta^{13} \mathrm{C}$ of different size classes (Marty and Planas, 2008).

Isotopic ratios of bacteria in field studies have been derived from re-growing bacteria in bioassays (Coffin et al., 1989) or dialysis cultures (Kritzberg et al., 2004), with measurement of ${ }^{13} \mathrm{C}$ in $\mathrm{POC}$ or respired $\mathrm{CO}_{2}(\mathrm{McC}$ allister and del Giorgio, 2008) and from biomarkers such as nucleic acids (Coffin et al., 1990) and lipids (Bontes et al., 2006; Pace et al., 2007). Some studies used $\delta^{13} \mathrm{C}$ of dissolved organic carbon (DOC) as proxy for $\delta^{13} \mathrm{C}$ of bacteria, assuming that DOC was the primary carbon source for bacteria (Taipale et al., 2008; Zigah et al., 2012).

A commonly used proxy for allochthonous $\delta^{13} \mathrm{C}$ is the $\delta^{13} \mathrm{C}$ of terrestrial $\mathrm{C}_{3}$ plants, which dominates most terrestrial vegetation and has a $\delta^{13} \mathrm{C}$ of $\sim-28 \%$ (Fry, 2006; Kohn, 2010). When vegetation is dominated by $\mathrm{C}_{4}$ plants, however, common in tropical areas and agricultural areas with maize production $\left(\delta^{13} \mathrm{C}\right.$ of $\sim-14 \%$; Fry, 2006), the isotopic composition of allochthonous carbon can be significantly enriched in ${ }^{13} \mathrm{C}$. In lakes with large terrestrial input, $\delta^{13} \mathrm{C}$ of DOC can be used as a proxy for $\delta^{13} \mathrm{C}_{\mathrm{allo}}$, since terrestrial carbon forms the largest fraction of DOC (Kritzberg et al., 2004; Wilkinson et al., 2013).

Compound-specific isotope analysis (CSIA) of polar lipidderived fatty acid (PLFA) biomarkers has shown to be a valuable tool to determine the isotopic composition of plankton producers and consumers (Boschker and Middelburg, 2002). Groups of phytoplankton and bacteria have different fatty acid (FA) compositions, so by analysing the $\delta^{13} \mathrm{C}$ of specific FA, the $\delta^{13} \mathrm{C}$ of phytoplankton and bacteria can be inferred. The combined use of stable isotopes and FA biomarkers has been successfully applied to study autochthonous and allochthonous carbon contributions to zooplankton in a tidal river (Van den Meersche et al., 2009). Few studies have applied CSIA to study carbon flows in plankton food webs in lakes. Examples are a phytoplankton-zooplankton interaction study in a eutrophic lake (Pel et al., 2004), a biomanipulation effect study (Bontes et al., 2006), a ${ }^{13} \mathrm{C}$ lake enrichment study (Pace et al., 2007) and a cyanobacteria-zooplankton interaction study (de Kluijver et al., 2012).

In this study, we used compound-specific isotope analyses to examine carbon flows in plankton food webs in temperate (North American) lakes. The lake survey encompassed a range in trophic states from oligotrophic lakes, with an expected dominance of allochthonous input, to eutrophic lakes, with an expected lower allochthonous input. In this trophic range, we explored patterns of isotopic variability in DIC, DOC,POC, carbohydrates, phytoplankton, allochthonous carbon and heterotrophic bacteria, and their relationships.
Table 2. Significant correlation coefficients $(r)$ between tested variables in all lakes and in eutrophic and oligo-mesotrophic lakes separately. Significance levels: $* p<0.05, * * p<0.01, * * * p<0.001$.

\begin{tabular}{|c|c|c|c|}
\hline Variables & $\begin{array}{l}\text { Eutrophic lakes } \\
\qquad(n=11) r\end{array}$ & $\begin{array}{l}\text { Oligo-mesotrophic } \\
\quad \text { lakes }(n=11) r\end{array}$ & $\begin{array}{r}\text { Overall } \\
(n=22) r\end{array}$ \\
\hline $\log$ alkalinity and $\log p \mathrm{CO}_{2}$ & $0.79 * *$ & & \\
\hline DIC and $\log p \mathrm{CO}_{2}$ & $0.82 * *$ & & \\
\hline $\mathrm{pH}$ and $\log p \mathrm{CO}_{2}$ & $-0.98 * * *$ & & \\
\hline $\log \mathrm{C}_{\text {phyto }}$ and $\log p \mathrm{CO}_{2}$ & $-0.80 * *$ & & $-0.59 * * *$ \\
\hline DOC and $\log p \mathrm{CO}_{2}$ & & $0.75 * *$ & \\
\hline $\log \mathrm{TP}$ and $\log \mathrm{C}_{\text {phyto }}$ & $0.61 *$ & $0.77 * *$ & $0.89 * * *$ \\
\hline $\log$ TP and $\log C_{b a c}$ & $0.74 * *$ & & $0.82 * * *$ \\
\hline $\log p \mathrm{CO}_{2}$ and $\delta^{13} \mathrm{C}_{\mathrm{DIC}}$ & $-0.63 *$ & $-0.81 * *$ & $-0.48 *$ \\
\hline POC and $\delta^{13} \mathrm{C}_{\text {DIC }}$ & $0.61 *$ & & \\
\hline DOC and $\delta^{13} \mathrm{C}_{\text {DIC }}$ & & $-0.62 *$ & \\
\hline $\log \mathrm{TP}$ and $\Delta\left(\delta_{\text {gluc }}-\delta_{\mathrm{FA}}\right)$ & & & $0.52 *$ \\
\hline $\log \mathrm{C}_{\text {phyto }}$ and $\delta^{13} \mathrm{C}_{\text {phyto }}$ & $0.90 * * *$ & & \\
\hline $\log p \mathrm{CO}_{2}$ and $\delta^{13} \mathrm{C}_{\text {phyto }}$ & $-0.79 * *$ & $-0.90 * * *$ & $-0.73 * * *$ \\
\hline$\delta^{13} \mathrm{C}_{\mathrm{CO}_{2}}$ and $\delta^{13} \mathrm{C}_{\text {phyto }}$ & & $0.82 * *$ & $0.54 * *$ \\
\hline $\log \mathrm{C}_{\text {phyto }}$ and $\varepsilon$ & $-0.70 *$ & & \\
\hline$\delta^{13} \mathrm{C}_{\mathrm{DOC}}$ and $\delta^{13} \mathrm{C}_{\text {detritus }}$ & & $0.79 * *$ & $0.54 *$ \\
\hline
\end{tabular}

\section{Material and methods}

\subsection{Site description}

The 22 lakes sampled in this study are located in Iowa and Itasca County in Minnesota, USA. Iowa lakes are mostly man-made and situated in a highly agricultural region, with maize and soya beans as main products. This type of rowcrop agriculture has a large impact on the nutrient load of the lake watershed (Arbuckle and Downing, 2001). Itasca lakes are natural and situated in a highly forested area.

The catchment areas have developed since the last glaciation episode ca. 12000 years ago and consist of carbonatepoor glacial deposits (till) (Grimley, 2000).

\subsection{Field sampling}

The lakes were sampled in July-August 2009 as part of the ongoing lake monitoring programme of the limnology laboratories of Iowa State University and Itasca Community College. Key parameters, such as temperature, $\mathrm{pH}$, Secchi transparency, oxygen, inorganic nutrients and carbon concentrations were measured as part of and according to the lake monitoring programme. All samples were taken from up to $2 \mathrm{~m}$ of the upper mixed zone at the deepest point of each lake. Water samples were taken between 10:00 and 16:00 LT, a period of the day that yields relatively stable water chemistry readings in these lakes. More information on data collection, lake characteristics and methods can be found on http:// limnoweb.eeob.iastate.edu/itascalakes and http://limnology. eeob.iastate.edu/lakereport. All nutrients were analysed using certified methods and strict quality assurance procedures.

Triplicate water samples were taken for stable isotope analyses and concentrations of the major carbon pools. Headspace vials ( 20 and $2 \mathrm{~mL}$ ) were filled on board with sampled water using the overflow method and sealed with 


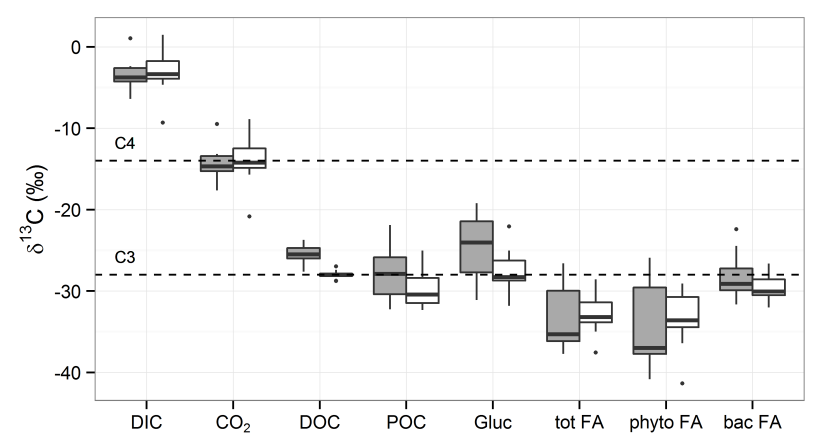

Figure 2. Box and whisker plot of the $\delta^{13} \mathrm{C}$ of inorganic and organic carbon pools in eutrophic lakes (grey boxes, $n=11$ ) and oligomesotrophic lakes (white boxes, $n=11$ ). The dashed lines present typical values for $\mathrm{C}_{3}$ and $\mathrm{C}_{4}$ vegetation.

gas-tight caps for DIC isotope analyses and concentrations, respectively. Mercury chloride was added for preservation and the samples were stored upside-down at room temperature. For DOC analyses, $20 \mathrm{~mL}$ of sampled water was filtered over GF/F $(0.7 \mu \mathrm{m}$ pore size, $25 \mathrm{~mm}$ diameter) and stored frozen in clean (acid and Milli-Q rinsed) vials until further analysis.

Seston samples for POC and carbohydrates were collected by filtering 0.4 to $1 \mathrm{~L}$ of sampled water on pre-weighed and pre-combusted $\mathrm{GF} / \mathrm{F}$ filters $(0.7 \mu \mathrm{m}$ pore size, $47 \mathrm{~mm}$ diameter), which were subsequently dried at $60^{\circ} \mathrm{C}$ for POC analysis or freeze-dried for carbohydrates; PLFA samples were collected by filtering $\sim 2 \mathrm{~L}$ sampled water on pre-combusted $\mathrm{GF} / \mathrm{F}$ filters $(0.7 \mu \mathrm{m}, 47 \mathrm{~mm})$ and filters were stored frozen. Pigment samples were taken for concentrations only and collected by filtering $\sim 600 \mathrm{~mL}$ sampled water on $\mathrm{GF} / \mathrm{F}$ filters $(0.7 \mu \mathrm{m}, 47 \mathrm{~mm})$ in the dark and filters were stored frozen.

\subsection{Laboratory analyses}

POC samples were analysed for carbon content and isotope ratios on a Thermo Electron Flash EA 1112 analyser (EA) coupled to a Delta $\mathrm{V}$ isotope ratio mass spectrometer (IRMS) (cf. Nieuwenhuize et al., 1994). For DIC isotope analyses, a helium headspace was created in the headspace vials and samples were acidified with $\mathrm{H}_{3} \mathrm{PO}_{4}$ solution. After equilibration, the $\mathrm{CO}_{2}$ concentration and isotope ratio in the headspace were measured using EA-IRMS (Gilikin and Bouillon, 2007). DIC concentrations were measured using spectrophotometry according to Stoll et al. (2001). For DOC analyses, the samples were acidified and flushed with helium to remove DIC and subsequently oxidized with sodium persulfate $\left(\mathrm{Na}_{2} \mathrm{~S}_{2} \mathrm{O}_{8}\right)$; the isotope ratio and concentration of $\mathrm{CO}_{2}$ resulting from this treatment was measured using high performance liquid chromatography - isotope ratio mass spectrometry (HPLC-IRMS) (Boschker et al., 2008). PLFA samples were extracted according to a modified Bligh and Dyer method (Bligh and Dyer, 1959, Mid- delburg et al., 2000). The lipids were fractionated in different polarity classes by column separation on a heat-activated silicic acid column and subsequent elution with chloroform, acetone and methanol. The methanol fractions, containing most of the PLFAs, were collected and transformed to fatty acid methyl esters (FAME) using methanolic $\mathrm{NaOH}$. The 12:0 and 19:0 FAME were added as internal standards. Concentrations and $\delta^{13} \mathrm{C}$ of individual PLFAs were measured using gas chromatography-combustion isotope ratio mass spectrometry (GC-C-IRMS) (Middelburg et al., 2000). The isotopic compositions were corrected for the carbon added during derivatization. Pigment samples were extracted with $90 \%$ acetone in purified (Milli-Q) water with intense shaking. Concentrations of individual pigments were measured on HPLC (Wright, 1991). Carbohydrate samples were hydrolysed in $\mathrm{H}_{2} \mathrm{SO}_{4}$, neutralized with $\mathrm{SrCO}_{3}$, and precipitated with $\mathrm{BaSO}_{4}$. The supernatant was collected and measured using HPLC-IRMS according to Boschker et al. (2008).

\subsection{Data analyses}

The lakes were divided into eutrophic and oligo-mesotrophic lakes based on average summer total phosphorus (TP) concentrations. Lakes with TP values $>24 \mu \mathrm{g} \mathrm{L}^{-1}$ and a corresponding trophic state index $>50$ were classified as eutrophic, and lakes with TP values $<24 \mu \mathrm{gL}^{-1}$ as oligomesotrophic (Carlson, 1977). All lakes in Iowa and one lake in Minnesota were classified as eutrophic, while all oligomesotrophic lakes were located in Minnesota.

\subsection{1 $\mathrm{CO}_{2}$ system and isotopic composition of $\mathrm{CO}_{2}$}

The different components of the $\mathrm{CO}_{2}$ system were calculated from temperature, laboratory $\mathrm{pH}$ and DIC concentrations using a salinity of 0 and the R package AquaEnv (Hofmann et al., 2010). Stable isotope ratios were expressed in the delta notation $\left(\delta^{13} \mathrm{C}\right)$, which is the ${ }^{13} \mathrm{C} /{ }^{12} \mathrm{C}$ ratio relative to VPDB standard, in parts per thousand (\%o). The isotope ratio of $\mathrm{CO}_{2}$ (aq) $\left(\delta^{13} \mathrm{C}_{\mathrm{CO}_{2}}\right)$ was calculated from $\delta^{13} \mathrm{C}_{\mathrm{DIC}}$ according to Zhang et al. (1995):

$$
\begin{aligned}
& \delta^{13} \mathrm{C}_{\mathrm{CO}_{2}}=\delta^{13} \mathrm{C}_{\mathrm{DIC}}-0.0144 \cdot T\left({ }^{\circ} \mathrm{C}\right) \cdot f \mathrm{CO}_{3}^{2-} \\
& \quad+0.107 \cdot T\left({ }^{\circ} \mathrm{C}\right)-10.53,
\end{aligned}
$$

where $f \mathrm{CO}_{3}^{2-}$ is the fraction of $\mathrm{CO}_{3}^{2-}$ in total DIC, calculated from $\mathrm{pH}$ and DIC concentrations.

\subsection{2 $\quad \delta^{13} \mathrm{C}$ of phytoplankton and bacteria}

Poly-unsaturated fatty acids (PUFAs) are abundant in most phytoplankton, and can generally be used as chemotaxonomic markers for this group (Dijkman and Kromkamp, 2006). The most abundant PUFAs in all lakes were 18:3 $\omega 3$

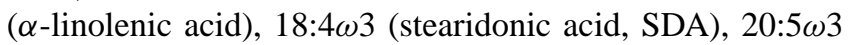
(icosapentaenoic acid, EPA), 22:6 $\omega 3$ (docosahexaenoic acid, DHA) and 20:4 $\omega 6$ (arachidonic acid, ARA), common 

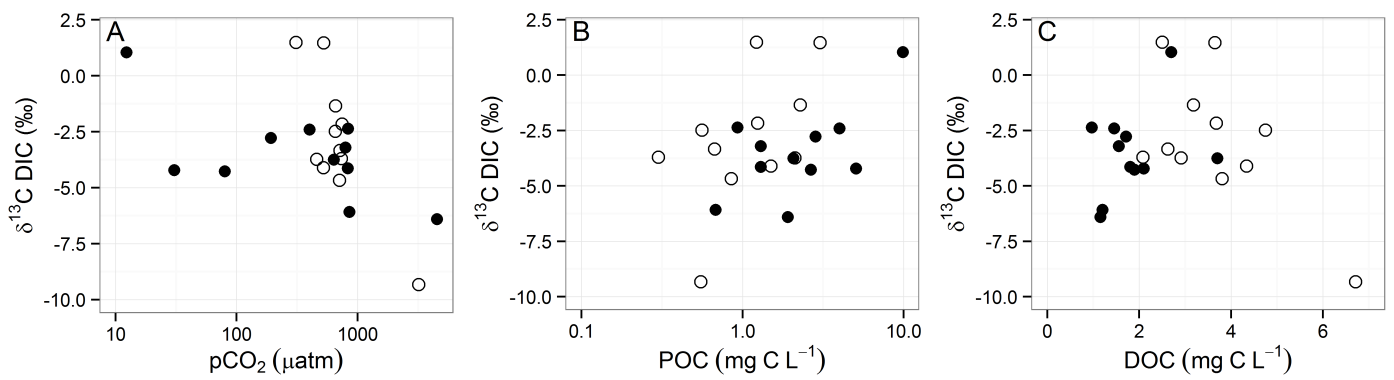

Figure 3. The relation of $\delta^{13} \mathrm{C}_{\mathrm{DIC}}$ in eutrophic lakes (filled circles, $n=11$ ) and oligo-mesotrophic lakes (open circles, $\left.n=11\right)$ to (a) $p \mathrm{CO}_{2}$; (b) $\mathrm{C}_{\text {phyto }}$; (c) DOC.

PUFAs in freshwater phytoplankton (Taipale et al., 2013), and their concentration-weighted $\delta^{13} \mathrm{C}$ were used to determine phytoplankton isotope ratios $\left(\delta^{13} \mathrm{C}_{\text {phyto }}\right)$. Note that phytoplankton is considered a mixture of eukaryotic algae and cyanobacteria. Branched fatty acids (BFAs) are abundant in heterotrophic bacteria (Kaneda, 1991) in contrast to phytoplankton. The most abundant BFAs were i15:0, ai15:0 and i17:0 and their weighted $\delta^{13} \mathrm{C}$ were used as a proxy for heterotrophic bacteria isotope ratios $\left(\delta^{13} \mathrm{C}_{\mathrm{bac}}\right)$, which we further consider bacteria. Isotope fractionation $(\varepsilon)$ between $\mathrm{CO}_{2}$ and phytoplankton was calculated as

$\varepsilon_{\mathrm{CO}_{2}-\text { phyto }}(\% o)=\frac{\delta^{13} \mathrm{C}_{\mathrm{CO}_{2}}-\delta^{13} \mathrm{C}_{\text {phyto }_{\text {cor }}}}{1+\delta^{13} \mathrm{C}_{\text {phyto }_{\text {cor }}} / 1000}$.

$\delta^{13} \mathrm{C}_{\text {phyto }_{\text {cor }}}$ was derived from $\delta^{13} \mathrm{C}_{\text {phyto }}$ with a correction of $+3 \%$ for the isotopic offset between PUFAs and total cells $\left(\Delta \delta^{13} \mathrm{C}_{\mathrm{FA}-\mathrm{cell}}\right)$ (Schouten et al., 1998; Hayes, 2001), although this isotopic offset can be highly variable (Schouten et al., 1998).

\subsection{3 $\quad \delta^{13} \mathrm{C}$ of allochthonous carbon}

Allochthonous organic carbon $\left(\delta^{13} \mathrm{C}_{\text {allo }}\right)$, i.e. organic matter delivered to lakes as DOC or POC, cannot be measured directly and we therefore used two proxies: the measured isotopic ratios of DOC $\left(\delta^{13} \mathrm{C}_{\mathrm{DOC}}\right)$ and calculated isotopic composition of particulate detritus $\left(\delta^{13} \mathrm{C}_{\mathrm{det}}\right)$. The latter was calculated from a mass balance and mixing model, similar to Marty and Planas (2008), amended with zooplankton and bacteria. We assumed that POC consists of phytoplankton, detritus, bacteria and zooplankton, and that the $\delta^{13} \mathrm{C}$ of POC represents a mixture of the weighted $\delta^{13} \mathrm{C}$ of the individual groups. Subsequently, $\delta^{13} \mathrm{C}_{\mathrm{det}}$ in each lake was derived from $\delta^{13} \mathrm{C}_{\mathrm{POC}}$ :

$$
\begin{aligned}
\delta^{13} \mathrm{C}_{\mathrm{det}}(\% o) & =\left(\mathrm{POC} \cdot \delta^{13} \mathrm{C}_{\mathrm{POC}}-\mathrm{C}_{\mathrm{phyto}} \cdot \delta^{13} \mathrm{C}_{\text {phyto }}{ }_{\text {cor }}\right. \\
& \left.-\mathrm{C}_{\mathrm{bac}} \cdot \delta^{13} \mathrm{C}_{\mathrm{bac}}-\mathrm{C}_{\mathrm{zoo}} \cdot \delta^{13} \mathrm{C}_{\mathrm{zoo}}\right) / \mathrm{C}_{\mathrm{det}} \\
\mathrm{C}_{\mathrm{det}}\left(\mathrm{mg} \mathrm{CL}{ }^{-1}\right) & =\mathrm{POC}-\mathrm{C}_{\text {phyto }}-\mathrm{C}_{\mathrm{bac}}-\mathrm{C}_{\mathrm{zoo}} .
\end{aligned}
$$

Equation (4) simply states that detrital organic matter is the non-living part of the total particulate organic matter pool.
Phytoplankton carbon $\left(\mathrm{C}_{\text {phyto }}\right)\left(\mathrm{mg} \mathrm{C} \mathrm{L}^{-1}\right)$ was calculated as the average of biomass estimates based on chl $a$ concentration (C: chl $a=50)$ as well as phytoplankton FA derived biomass, to minimize the error associated with each method. Phytoplankton FA biomass was calculated from the sum of phytoplankton PLFAs $\left(\sum 18: 3 \omega 3,18: 4 \omega 3,20: 5 \omega 3,22: 6 \omega 3\right.$,

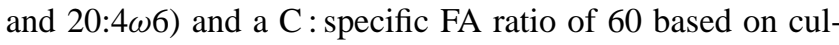
ture studies, summarized in Dijkman and Kromkamp (2006). The two approaches yielded similar results. Bacterial carbon $\left(\mathrm{C}_{\mathrm{bac}}\right)\left(\mathrm{mg} \mathrm{C} \mathrm{L}^{-1}\right)$ was calculated from the summed concentrations of bacteria-specific FA (i15:0, ai15:0, and i17:0) and a $C_{b a c}$ : FA ratio of 50 (Middelburg et al., 2000). Zooplankton carbon $\left(\mathrm{C}_{\mathrm{zoo}}\right)$ used in Eq. (3) was estimated to be $\sim 10 \%$ of $\mathrm{C}_{\text {phyto }}$ (Del Giorgio and Gasol, 1995) and zooplankton $\delta^{13} \mathrm{C}$ are based on de Kluijver (2012). Uncertainties in $\delta^{13} \mathrm{C}$ and biomass of phytoplankton, bacteria and zooplankton were not considered in calculating $\delta^{13} \mathrm{C}_{\text {det }}$.

\subsubsection{Statistical analyses}

Data that were part of the lake monitoring programme and $p \mathrm{CO}_{2}$ values represent single samples of each lake. Data on carbon concentrations and isotopic compositions in each lake convey averages of triplicate samples. Statistical analyses were done with software package " $\mathrm{R}$ " ( $\mathrm{R}$ development core team, 2013). Prior to correlation analyses, data were checked for normal distribution (Shapiro test) and log-transformed when necessary to achieve normal distribution. Correlation coefficients were calculated using Pearson product-moment correlation coefficient (normal distribution) or Spearman's rank correlation coefficient (non-normal distribution). For completeness we present the average \pm sd values for eutrophic lakes $(n=11)$ and oligo-mesotrophic lakes $(n=11)$, but we do realize that any division based on a concentration is somewhat arbitrary. The correlations were tested for total lakes $(n=22)$ and for eutrophic lakes $(n=11)$ and oligomesotrophic lakes $(n=11)$. Differences between eutrophic and oligo-mesotrophic lakes were statistically tested using Student's $t$ tests. 


\section{Results}

\subsection{Lake chemistry}

The sampled lakes covered a large range of nutrients and $\mathrm{CO}_{2}$ system characteristics (Table 1). DIC values ranged from 0.05 to $4.55 \mathrm{mmol} \mathrm{L}^{-1}$, alkalinity values ranged from 0.070 to $2.4 \mathrm{mmol} \mathrm{L}^{-1}$ and $\mathrm{pH}$ ranged from 6.1 to 9.8 (Table 1). The calculated $p \mathrm{CO}_{2}$ values were in the range

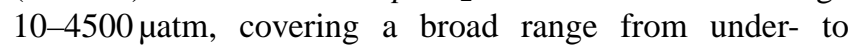
super-saturation. The $\mathrm{CO}_{2}$ system in eutrophic and oligomesotrophic lakes was clearly different. On average, the eutrophic lakes had higher DIC, alkalinity and $\mathrm{pH}$ than the oligo-mesotrophic lakes (Fig. 1, Table 1). In the eutrophic lakes, there were positive correlations between alkalinity and DIC and $p \mathrm{CO}_{2}$ values (Fig. 1a, Table 2) and a negative correlation between $\mathrm{pH}$ and $p \mathrm{CO}_{2}$ (Fig. 1b, Table 2). The $p \mathrm{CO}_{2}$ values were not related to $\mathrm{pH}$, alkalinity or DIC in the oligo-mesotrophic lakes. Both lake systems showed super-saturation (average $p \mathrm{CO}_{2} 838 \mu \mathrm{atm}$ in both), but the $p \mathrm{CO}_{2}$ range was much larger in eutrophic lakes (10-4500 $\mu \mathrm{atm})$ compared to oligo-mesotrophic lakes (310-3200 $\mu$ atm) (Fig. 1, Table 1).

\subsection{Organic carbon and fatty acid concentrations}

POC, $\mathrm{C}_{\text {phyto }}$ and $\mathrm{C}_{\mathrm{bac}}$ concentrations were higher and DOC concentrations were lower in the eutrophic lakes compared to the oligo-mesotrophic lakes (Table 1). $\mathrm{C}_{\text {phyto }}$ was on average $1.32 \pm 1.10$ and $0.11 \pm 0.03 \mathrm{mg} \mathrm{CL}^{-1}$, corresponding to $44 \pm 17$ and $10 \pm 5 \%$ of POC in eutrophic and oligomesotrophic lakes, respectively. $\mathrm{C}_{\mathrm{phyto}}$ and $\mathrm{C}_{\mathrm{bac}}$ were significantly related to TP (Table 2), but not to TN. Average $\mathrm{C}_{\mathrm{bac}}$ was $0.114 \pm 0.081$ and $0.021 \pm 0.017 \mathrm{mg} \mathrm{CL}^{-1}$ in eutrophic and oligo-mesotrophic lakes, respectively.

Overall, lake $p \mathrm{CO}_{2}$ decreased with increasing $\mathrm{C}_{\text {phyto }}$, but the effect was strongest in eutrophic lakes (Fig. 1c, Table 2). In the oligo-mesotrophic lakes, $p \mathrm{CO}_{2}$ increased with increasing DOC (Fig. 1d, Table 2), but this effect was caused by one point: the high $p \mathrm{CO}_{2}$ at high DOC in lake Sturgeon. In the eutrophic lakes, DOC concentrations were lower compared to the oligo-mesotrophic lakes and did not act on lake $p \mathrm{CO}_{2}$ (Fig. 1d, Table 1).

\section{$3.3 \delta^{13} \mathrm{C}$ of DIC and $\mathrm{CO}_{2}$}

The isotope ratios of the major carbon pools in each lake are presented in Table 3 and in box plots (median and percentiles) in Fig. 2. $\delta^{13} \mathrm{C}_{\text {DIC }}$ ranged from -9.3 to $+1.5 \%$ and $\delta^{13} \mathrm{C}_{\mathrm{CO}_{2}}$ (derived from $\delta^{13} \mathrm{C}_{\text {DIC }}$ ) was on average $10.9 \pm 0.3 \%$ o depleted in ${ }^{13} \mathrm{C}$ relative to DIC, with a range of -20.8 to $-8.9 \%$. $\delta^{13} \mathrm{C}_{\mathrm{DIC}}$ and $\delta^{13} \mathrm{C}_{\mathrm{CO}_{2}}$ showed no correlation with alkalinity, DIC, $\mathrm{pH}$, temperature and lake area. A weak negative relation between $p \mathrm{CO}_{2}$ and $\delta^{13} \mathrm{C}_{\text {DIC }}$ was observed, which was stronger in oligo-mesotrophic lakes than in eutrophic lakes (Fig. 3a, Table 2). The highest $p \mathrm{CO}_{2}$ lakes had the lowest $\delta^{13} \mathrm{C}_{\mathrm{DIC}}$, suggesting that respiration of organic matter influenced $\delta^{13} \mathrm{C}_{\text {DIC }}$. Low $\mathrm{CO}_{2}$ lakes had enriched $\delta^{13} \mathrm{C}_{\text {DIC }}$, indicating influence of primary production. Weak but significant relations were observed for POC and DOC with $\delta^{13} \mathrm{C}_{\text {DIC }}$ (Table 2). In eutrophic lakes, $\delta^{13} \mathrm{C}_{\text {DIC }}$ increased with increasing POC (Fig. 3b, Table 2), while in oligo-mesotrophic lakes, $\delta^{13} \mathrm{C}_{\mathrm{DIC}}$ decreased with increasing DOC (Fig. 3c, Table 2).

\section{$3.4 \quad \delta^{13} \mathrm{C}$ of organic carbon pools}

The isotopic composition of DOC $\left(\delta^{13} \mathrm{C}_{\mathrm{DOC}}\right)$ had the narrowest range of all carbon pools, only -28.8 to $-27.0 \%$ o (mean $-28.0 \%$ ) in the oligo-mesotrophic lakes and a slightly larger range of -27.6 to $-23.7 \%$ (mean $-25.4 \%$ o) in the eutrophic lakes (Fig. 2, Table 3). The $\delta^{13} \mathrm{C}$ range of POC $\left(\delta^{13} \mathrm{C}_{\mathrm{POC}}\right)$ was larger than of DOC in both lake types and on average $2.0 \%$ lower compared to $\delta^{13} \mathrm{C}_{\mathrm{DOC}}$, with mean values of $-27.8 \pm 3.6 \%$ in eutrophic and $-29.7 \pm 2.8 \%$ in oligo-mesotrophic lakes (Fig. 2, Table 3). $\delta^{13} \mathrm{C}$ of particulate glucose $\left(\delta^{13} \mathrm{C}_{\text {gluc }}\right)$, the most abundant carbohydrate, was always enriched in ${ }^{13} \mathrm{C}$ compared to $\delta^{13} \mathrm{C}_{\mathrm{POC}}$ and the enrichment was similar in eutrophic $(3.1 \pm 1.7 \%$ o $)$ and oligo-mesotrophic lakes $(2.8 \pm 1.5 \%$ ) (Fig. 2). On the contrary, the concentration-weighted average $\delta^{13} \mathrm{C}$ of all FA $\left(\delta^{13} \mathrm{C}_{\mathrm{FA}}\right.$ tot $)$ was always depleted in ${ }^{13} \mathrm{C}$ compared to $\delta^{13} \mathrm{C}_{\mathrm{POC}}$ (Fig. 2). The depletion in ${ }^{13} \mathrm{C}$ of $\delta^{13} \mathrm{C}_{\mathrm{FA}_{\text {tot }}}$ relative to POC was higher in eutrophic lakes $(5.2 \pm 1.8 \%$ o) than in oligo-mesotrophic lakes $(3.1 \pm 1.1 \%$ o). The isotopic difference between glucose and $\delta^{13} \mathrm{C}_{\mathrm{FA}_{\mathrm{tot}}}: \Delta \delta^{13} \mathrm{C}_{\mathrm{gluc}-\mathrm{FA}_{\mathrm{tot}} \text { was }}$ highly variable with a range of 1.6 to $14.6 \%$. The isotopic differences between glucose and $\delta^{13} \mathrm{C}_{\mathrm{FA}_{\text {tot }}}$ did not correlate with $\mathrm{CO}_{2}$, but correlated weakly with nutrient levels, i.e. $\Delta \delta^{13} \mathrm{C}_{\text {gluc- }-\mathrm{FA}_{\text {tot }}}$ increased with increasing TP (Table 2).

There was a large variability among $\delta^{13} \mathrm{C}$ of different FA, with some consistent differences over all lakes. Compared to the $\delta^{13} \mathrm{C}$ of 16:0 (the most abundant FA), the bacterial FA markers were always enriched in ${ }^{13} \mathrm{C}$ by $1.4-5.0 \%$ (e.g. the iso-15:0 FA in Fig. 4), therefore the overall $\delta^{13} \mathrm{C}$ of bacterial FA $\left(\delta^{13} \mathrm{C}_{\mathrm{bac}}\right)$ was more ${ }^{13} \mathrm{C}$-enriched than $\delta^{13} \mathrm{C}_{\mathrm{FA}}$ tot in both lake systems (Fig. 2). The PUFAs used as markers for phytoplankton showed consistent differences throughout the lakes. DHA (22:6 $\omega 3$ ), common in dinoflagellates (Dalsgaard et al., 2003), was found to be ${ }^{13} \mathrm{C}$-enriched with $4.6 \%$ o compared to $16: 0$ while PLFA 18:3 $\omega 3$ ( $\alpha$-linolenic acid), common in cyanobacteria (de Kluijver et al., 2012), was $4.7 \%$ o depleted in ${ }^{13} \mathrm{C}$ compared to $16: 0$ (Fig. 4). The other phytoplankton markers were not statistically different from 16:0. The weighted $\delta^{13} \mathrm{C}$ of phytoplankton FA $\left(\delta^{13} \mathrm{C}_{\text {phyto }}\right)$ was the most ${ }^{13} \mathrm{C}$-depleted of all carbon pools (Fig. 2, Table 3 ) with an average of $-33.8 \pm 5.3$ in eutrophic lakes and $-33.4 \pm 3.5 \%$ in oligo-mesotrophic lakes. $\delta^{13} \mathrm{C}_{\mathrm{bac}}$ were on average $4.7 \%$ enriched in ${ }^{13} \mathrm{C}$ compared to $\delta^{13} \mathrm{C}_{\text {phyto }}$ (Fig. 2). 
Table 3. Carbon isotope values of sampled lakes. Isotope data are presented as average $\pm \mathrm{SD}(n=3) . \delta^{13} \mathrm{C}_{\mathrm{CO}_{2}}$ was calculated from $\delta^{13} \mathrm{C}_{\mathrm{DIC}}$ (Eq. 1). $\delta^{13} \mathrm{C}_{\text {phyto }}$ and $\delta^{13} \mathrm{C}_{\mathrm{bac}}$ are not corrected for the offset between fatty acids and total cells, but $\varepsilon_{\mathrm{CO}_{2}}-$ phyto $($ Eq. 2) used the corrected $\delta^{13} \mathrm{C}$ of phytoplankton.

\begin{tabular}{|c|c|c|c|c|c|c|c|c|c|}
\hline Lake name & Trophic state & $\delta^{13} \mathrm{C}_{\mathrm{DIC}}(\% \circ)$ & $\delta^{13} \mathrm{C}_{\mathrm{CO}_{2}}(\% o)$ & $\delta^{13} \mathrm{C}_{\mathrm{POC}}(\% \circ)$ & $\delta^{13} \mathrm{C}_{\text {DOC }}(\% o)$ & $\delta^{13} \mathrm{C}_{\text {phyto }}(\% o)$ & ${ }^{\varepsilon} \mathrm{CO}_{2}-$ phyto & $\delta^{13} \mathrm{C}_{\mathrm{bac}}(\% o)$ & $\delta^{13} \mathrm{C}_{\text {gluc }}(\% o)$ \\
\hline Beaver (I) & $\mathrm{Eu}$ & $-4.2 \pm 0.6$ & -15.2 & $-21.9 \pm 0.2$ & $-24.2 \pm 0.0$ & $-25.9 \pm 1.9$ & 7.8 & $-22.4 \pm 0.3$ & -19.2 \\
\hline Beeds (I) & $\mathrm{Eu}$ & $-2.4 \pm 0.1$ & -13.1 & -32.2 & $-23.7 \pm 0.1$ & $-38.0 \pm 2.5$ & 22.7 & $-29.1 \pm 0.0$ & -31.1 \\
\hline Big Creek (I) & $\mathrm{Eu}$ & $-3.2 \pm 0.1$ & -14.1 & $-32.2 \pm 0.1$ & $-26.4 \pm 0.9$ & $-40.8 \pm 2.2$ & 24.7 & $-31.5 \pm 0.7$ & -30.4 \\
\hline Coralville (I) & $\mathrm{Eu}$ & $-6.4 \pm 0.0$ & -17.6 & $-27.9 \pm 0.5$ & $-24.6 \pm 0.3$ & $-37.4 \pm 1.5$ & 17.4 & $-29.4 \pm 0.9$ & -21.4 \\
\hline Little Split-hand (M) & $\mathrm{Eu}$ & $-3.8 \pm 0.1$ & -14.7 & $-32.3 \pm 0.4$ & $-27.6 \pm 0.4$ & $-37.0 \pm 0.5$ & 20.0 & $-31.7 \pm 0.7$ & -27.3 \\
\hline Lower Pine (I) & $\mathrm{Eu}$ & $-2.4 \pm 0.1$ & -13.2 & $-26.2 \pm 0.2$ & $-25.3 \pm 0.5$ & $-30.6 \pm 1.1$ & 14.8 & $-27.2 \pm 0.8$ & -24.0 \\
\hline McBride (I) & $\mathrm{Eu}$ & $-2.8 \pm 0.1$ & -13.6 & $-25.6 \pm 0.4$ & $-25.6 \pm 0.3$ & $-27.3 \pm 0.6$ & 11.0 & $-27.2 \pm 1.0$ & -21.5 \\
\hline Meyers (I) & $\mathrm{Eu}$ & $1.0 \pm 0.3$ & -9.5 & $-22.1 \pm 0.1$ & $-26.2 \pm 0.6$ & $-29.3 \pm 1.7$ & 17.3 & $-24.5 \pm 0.6$ & -19.7 \\
\hline Rodgers Park (I) & $\mathrm{Eu}$ & $-6.1 \pm 0.0$ & -17.3 & -29.0 & $-24.8 \pm 0.3$ & -38.6 & 19.0 & -30.3 & -26.3 \\
\hline Saylorville (I) & $\mathrm{Eu}$ & $-4.1 \pm 0.0$ & -15.1 & $-29.2 \pm 0.1$ & $-25.8 \pm 1.2$ & $-37.3 \pm 1.4$ & 19.8 & $-29.5 \pm 0.4$ & -28.1 \\
\hline Three Mile (I) & $\mathrm{Eu}$ & $-4.3 \pm 0.3$ & -15.3 & $-27.8 \pm 0.4$ & $-25.5 \pm 1.0$ & $-29.8 \pm 2.3$ & 11.9 & $-28.5 \pm 0.6$ & -23.7 \\
\hline Beaver (M) & $\mathrm{O}-\mathrm{M}$ & $-4.1 \pm 0.5$ & -15.1 & $-30.5 \pm 0.2$ & $-28.7 \pm 0.2$ & $-32.4 \pm 0.2$ & 14.8 & $-30.4 \pm 2.0$ & -28.3 \\
\hline Brush Shanty (M) & $\mathrm{O}-\mathrm{M}$ & $-2.5 \pm 0.2$ & -13.3 & $-29.6 \pm 0.2$ & $-28.1 \pm 0.4$ & $-33.6 \pm 2.1$ & 17.9 & $-30.0 \pm 3.0$ & -25.0 \\
\hline Hatch (M) & $\mathrm{O}-\mathrm{M}$ & $-3.7 \pm 0.1$ & -14.6 & $-31.4 \pm 0.4$ & $-28.8 \pm 0.2$ & $-34.5 \pm 1.3$ & 17.4 & $-30.6 \pm 2.4$ & -28.6 \\
\hline Horsehead (M) & $\mathrm{O}-\mathrm{M}$ & $-3.7 \pm 0.9$ & -14.7 & $-25.0 \pm 0.1$ & $-27.0 \pm 0.1$ & $-29.1 \pm 0.7$ & 11.7 & $-27.8 \pm 2.0$ & \\
\hline Kelly (M) & $\mathrm{O}-\mathrm{M}$ & $1.5 \pm 0.5$ & -8.9 & $-27.8 \pm 0.7$ & $-27.9 \pm 0.4$ & $-30.1 \pm 1.0$ & 18.7 & $-26.6 \pm 2.6$ & -22.1 \\
\hline Leighton (M) & $\mathrm{O}-\mathrm{M}$ & $-3.3 \pm 0.0$ & -14.2 & $-32.3 \pm 0.3$ & $-28.2 \pm 0.7$ & $-34.4 \pm 1.3$ & 17.7 & $-30.9 \pm 1.3$ & -31.8 \\
\hline Little Sand (M) & $\mathrm{O}-\mathrm{M}$ & $-2.2 \pm 0.1$ & -12.9 & $-30.4 \pm 0.2$ & $-28.1 \pm 0.0$ & $-33.7 \pm 1.7$ & 18.4 & $-29.4 \pm 1.8$ & \\
\hline O’Leary (M) & $\mathrm{O}-\mathrm{M}$ & $-1.3 \pm 0.7$ & -12.0 & $-28.1 \pm 0.3$ & $-27.4 \pm 0.7$ & $-31.3 \pm 0.4$ & 16.7 & $-26.8 \pm 0.8$ & -26.3 \\
\hline Sand Lake (M) & $\mathrm{O}-\mathrm{M}$ & $-4.7 \pm 0.1$ & -15.7 & $-31.5 \pm 0.4$ & $-28.0 \pm 0.1$ & $-36.4 \pm 0.1$ & 18.3 & $-29.6 \pm 1.8$ & -28.7 \\
\hline South Sturgeon (M) & $\mathrm{O}-\mathrm{M}$ & $-9.3 \pm 0.1$ & -20.8 & $-31.8 \pm 0.9$ & $-28.0 \pm 0.0$ & $-41.4 \pm 1.4$ & 18.2 & $-30.5 \pm 1.2$ & -29.4 \\
\hline Thirty (M) & $\mathrm{O}-\mathrm{M}$ & $1.5 \pm 0.6$ & -8.9 & $-28.7 \pm 0.1$ & $-27.8 \pm 0.1$ & $-30.2 \pm 1.4$ & 18.8 & $-32.0 \pm 1.2$ & -26.4 \\
\hline
\end{tabular}

\subsection{Carbon isotopic composition of phytoplankton}

$\delta^{13} \mathrm{C}_{\text {phyto }}$ depends on the isotopic composition of substrate $\left(\delta^{13} \mathrm{C}_{\mathrm{CO}_{2}}\right)$, the isotope fractionation $\left(\varepsilon_{\mathrm{CO}_{2}-\text { phyto }}\right)$ associated with primary production and the isotopic difference between PUFAs and biomass. $\delta^{13} \mathrm{C}_{\text {phyto }}$ in the eutrophic lakes became more enriched in ${ }^{13} \mathrm{C}$ with increasing $\mathrm{C}_{\text {phyto }}$ (Fig. 5a, Table 2) and decreasing $p \mathrm{CO}_{2}$ (Fig. 5b, Table 2). No relation between $\delta^{13} \mathrm{C}_{\text {phyto }}$ and $\mathrm{C}_{\text {phyto }}$ was observed in the oligomesotrophic lakes (Fig. 5a), but there was a strong negative relation with $p \mathrm{CO}_{2}$ (Fig. 5b, Table 2). The influence of $\mathrm{C}_{\text {phyto }}$ on $\delta^{13} \mathrm{C}_{\text {phyto }}$ in the eutrophic lakes was also reflected in fractionation; $\varepsilon_{\mathrm{CO}_{2}}$-phyto was highly variable in eutrophic lakes, while it was less variable in oligotrophic lakes (Fig. 5c). The range of $\varepsilon \mathrm{CO}_{2}$-phyto was 7.8 to $24.7 \%$ (mean $16.9 \%$ ) in eutrophic and 11.7 to $18.8 \%$ (mean $17.1 \%$ ) in oligomesotrophic lakes, when $\delta^{13} \mathrm{C}_{\text {phyto }}$ was used (Table 3). The less variable $\varepsilon$ in oligo-mesotrophic lakes resulted in a strong correlation between $\delta^{13} \mathrm{C}_{\mathrm{CO}_{2}}$ and $\delta^{13} \mathrm{C}_{\text {phyto }}$ (Table 2), which was absent in the eutrophic lakes. $\varepsilon \mathrm{CO}_{2}$-phyto correlated negatively with $\mathrm{C}_{\text {phyto }}$ in eutrophic lakes, however (Table 2). The variability in $\delta^{13} \mathrm{C}_{\text {phyto }}$ in eutrophic lakes can be mainly attributed to the presence of two clusters: a ${ }^{13} \mathrm{C}$-enriched cluster at the highest $\mathrm{C}_{\text {phyto }}$ and a ${ }^{13} \mathrm{C}$-depleted cluster at lower $\mathrm{C}_{\text {phyto }}$ (Fig. 5a). Interestingly, the eutrophic lakes within the ${ }^{13} \mathrm{C}$-enriched cluster also had high concentrations of zeaxanthin, a marker pigment for cyanobacteria (data not shown here).

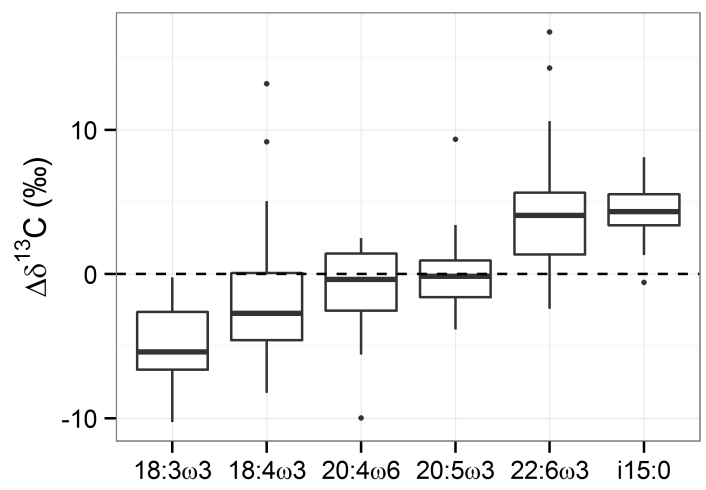

Figure 4. Box and whisker plots of the $\Delta \delta^{13} \mathrm{C}$ of individual biomarker fatty acids relative to $16: 0 \mathrm{FA}\left(\delta^{13} \mathrm{C}_{\mathrm{FA}}-\delta^{13} \mathrm{C}_{16: 0}\right)$ in all lakes.

\section{Discussion}

\subsection{Lake metabolism, $p \mathrm{CO}_{2}$ and $\delta^{13} \mathrm{C}_{\text {DIC }}$}

In our study, about three-quarters of the lakes were supersaturated with $p \mathrm{CO}_{2}$, consistent with the finding in the literature that lakes generally emit carbon dioxide to the atmosphere (Cole et al., 1994, 2007). This $\mathrm{CO}_{2}$ excess can be due to in-lake respiration of terrestrially derived organic carbon outbalancing $\mathrm{CO}_{2}$ fixation by primary producers (negative metabolic balance) or due to river and groundwater input of $\mathrm{CO}_{2}$-rich waters (McDonald et al., 2013). Lake metabolism also impacts $\delta^{13} \mathrm{C}_{\text {DIC }}$ dynamics. Previous studies have shown that $\delta^{13} \mathrm{C}$ of DIC in lakes is driven by carbonate chemistry, 
hydrology (i.e. groundwater inflow), and metabolic activity (Bade et al., 2004). Primary production increases $\delta^{13} \mathrm{C}_{\text {DIC }}$ because of the preferential uptake of ${ }^{12} \mathrm{C}$ (isotope fractionation), while organic matter respiration decreases $\delta^{13} \mathrm{C}_{\text {DIC }}$ (Fry, 2006).

If $p \mathrm{CO}_{2}$ and $\delta^{13} \mathrm{C}_{\mathrm{DIC}}$ had been only or primarily controlled by the balance between respiration and production of organic matter, one would expect a tight correlation between $\delta^{13} \mathrm{C}_{\mathrm{DIC}}$ and $p \mathrm{CO}_{2}$, which was not observed overall (Fig. 3a, Table 2), indicating that other factors are involved. High inorganic carbon loadings of inflowing rivers and groundwater inputs may sustain the $\mathrm{CO}_{2}$ excess (McDonald et al., 2013) and govern the $\delta^{13} \mathrm{C}_{\mathrm{DIC}}$ (Bade et al., 2004). Moreover, $\mathrm{CO}_{2}$ water-air exchange reactions may have modified $\delta^{13} \mathrm{C}_{\text {DIC }}$ values because of isotope fractionation during water-air exchange, in particular at high $\mathrm{pH} /$ low $\mathrm{CO}_{2}$ values (Herczeg and Fairbanks, 1987; Bade et al., 2004; Bontes et al., 2006).

The correlation between $\delta^{13} \mathrm{C}_{\mathrm{DIC}}$ and $p \mathrm{CO}_{2}$ in oligomesotrophic lakes was stronger (Table 2) and $p \mathrm{CO}_{2}$ was highest and $\delta^{13} \mathrm{C}_{\mathrm{DIC}}$ was most depleted in ${ }^{13} \mathrm{C}$ at the highest DOC in oligo-mesotrophic lakes (Figs. 1c, 3c). Such a depletion of $\delta^{13} \mathrm{C}_{\mathrm{DIC}}$ with increasing DOC, as an indicator of the importance of respiration in oligo-mesotrophic lakes, has been shown previously in North American lakes (Lennon et al., 2006). In addition to community respiration, methanotrophic bacteria in high DOC lakes could decrease $\delta^{13} \mathrm{C}_{\text {DIC }}$ (Jones et al., 1999). However, anoxic hypolimnia are rare in these lakes, due to either low nutrients or polymixis, indicating that methanogenesis was not of major importance in the lakes investigated. Furthermore, we examined the $\delta^{13} \mathrm{C}$ of fatty acids abundant in or specific to methanotrophs and these were not more depleted in ${ }^{13} \mathrm{C}$ than other fatty acids.

Note that the lakes were sampled at only one point location and depth, representing average conditions, so spatial variability per lake is not taken into account. Also diurnal variation and variation over the year in each lake are not considered in this study. However, the aim of our study is to compare snapshots of different lakes representing different metabolic states and not to describe the biogeochemistry of each individual lake. So, although we miss some variation, this should not affect our main findings on carbon isotope biogeochemistry of these lakes.

\subsection{Allochthonous $\delta^{13} \mathrm{C}$}

DOC and POC pools are mixtures of organic matter from various sources with potentially different stable carbon isotopic compositions. The POC pool comprises biomass from living organisms and remains from organisms within the lake as well as allochthonous detritus. The relative importance of living biomass to total POC pool, calculated based on Eq. (4), varies from 5.7 to $93 \%$ (Table 1), with on average about $53 \pm 20 \%$ in eutrophic lakes and only $13 \pm 5 \%$ in oligomesotrophic lakes. In our study we have explicit carbon iso- tope data for the most important living compartments (algae, bacteria and zooplankton; De Kluijver, 2012), but we have no direct measurement of the $\delta^{13} \mathrm{C}$ of organic carbon delivered from the watershed via atmospheric, riverine and groundwater inputs. We have therefore used two proxies for $\delta^{13} \mathrm{C}_{\text {allo }}$ : the carbon isotope ratio of DOC and that of detrital POC calculated by difference (Eqs. 3, 4). Both proxies for $\delta^{13} \mathrm{C}_{\text {allo }}$ provide an estimate for the total detrital pool, i.e. the sum of aquatic and terrestrial detritus.

The oligo-mesotrophic lakes are surrounded by forest $\left(\mathrm{C}_{3}\right.$ vegetation) and $\delta^{13} \mathrm{C}_{\mathrm{DOC}}$ was $-28.0 \pm 0.5 \%$, corresponding to $\mathrm{a}_{3}$ vegetation signal, suggesting that the DOC pool is dominantly terrestrially derived, consistent with a combined carbon and hydrogen isotope study of Wisconsin and Michigan lakes by Wilkinson et al. (2013). The other proxy for allochthonous carbon, $\delta^{13} \mathrm{C}_{\mathrm{det}}$, was slightly more negative $(-29.6 \pm 2.1 \%$ o) , but the two proxies for allochthonous carbon were well correlated (Table 2). The $1.6 \%$ lighter isotopic composition might reflect a relatively larger contribution of autochthonous detritus to the total detrital particulate organic matter pool than to the dissolved pool. Consistently with this, Wilkinson et al. (2013) reported that a lower contribution of terrestrial organic matter to the particulate pool than to the dissolved organic matter pools in North American lakes.

Allochthonous carbon proxies in eutrophic lakes were more ${ }^{13} \mathrm{C}$-enriched and variable: $-25.4 \pm 1.1 \%$ for $\delta^{13} \mathrm{C}_{\mathrm{DOC}}$ and $-26.6 \pm 4.2 \%$ for $\delta^{13} \mathrm{C}_{\mathrm{det}}$. Moreover, $\delta^{13} \mathrm{C}_{\mathrm{DOC}}$ and $\delta^{13} \mathrm{C}_{\mathrm{det}}$ were not significantly correlated. The enrichment in ${ }^{13} \mathrm{C}$ of $\delta^{13} \mathrm{C}_{\text {allo }}$ in eutrophic lakes can be partly explained by land use in the water shed; almost all eutrophic lakes were located in the state of Iowa, where an average of $92 \%$ of the land is under periodic cultivation for maize $\left(\mathrm{C}_{4}\right.$ plants, $-14 \%$ o). There was more uncertainty in $\delta^{13} \mathrm{C}_{\text {allo }}$ in the eutrophic lakes for two main reasons. First, we expect a substantial autochthonous contribution to DOC and detritus in productive lakes (Bade et al., 2007), which contributes to the larger range in $\delta^{13} \mathrm{C}_{\mathrm{DOC}}$ and $\delta^{13} \mathrm{C}_{\mathrm{det}}$ (Fig. 2). Second, the presence of $\mathrm{C}_{3}$ and $\mathrm{C}_{4}$ vegetation with their distinct isotopic compositions can create a variable $\delta^{13} \mathrm{C}_{\text {allo }}$. Variability in $\delta^{13} \mathrm{C}_{\text {allo }}$ has received far less attention than that of aquatic primary producers. Our results show distinct differences in the isotopic composition of external subsidies and argue against a fixed value for allochthonous carbon, especially in areas with abundant $\mathrm{C}_{4}$ vegetation, such as maize.

\subsection{Phytoplankton $\delta^{13} \mathrm{C}$}

The determination of $\delta^{13} \mathrm{C}_{\text {phyto }}$ is one of the major challenges in aquatic ecology. Fatty acid biomarkers as proxies for $\delta^{13} C_{\text {phyto }}$ have the advantage that there is a larger certainty that measured $\delta^{13} \mathrm{C}$ values represent parts of phytoplankton carbon. The main uncertainty using $\delta^{13} \mathrm{C}_{\mathrm{FA}}$ as marker for $\delta^{13} \mathrm{C}_{\text {phyto }}$ comes from the isotopic offset between lipids and total cells $\left(\Delta \delta^{13} \mathrm{C}_{\mathrm{FA}-\text { cell }}\right)$ which depends 

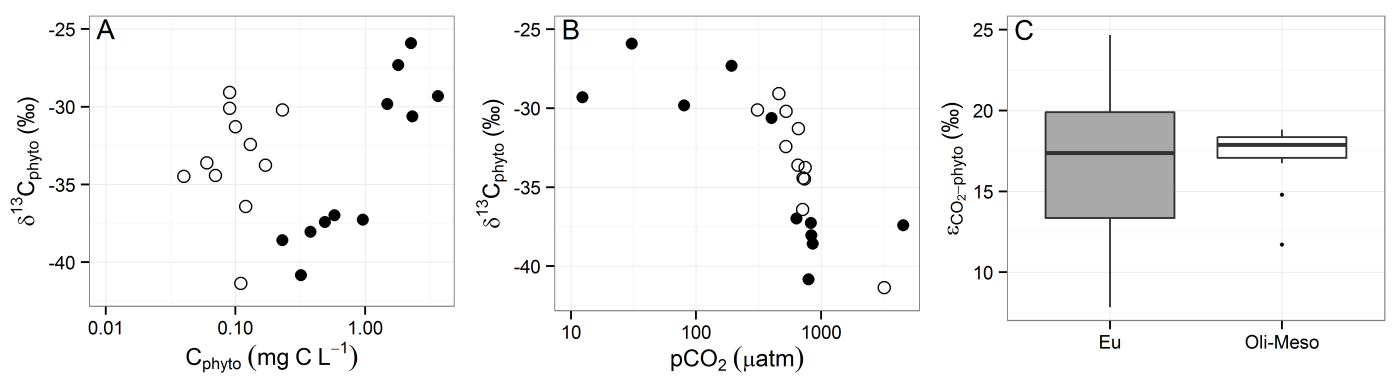

Figure 5. The relation of $\delta^{13} \mathrm{C}_{\text {phyto }}$ in eutrophic lakes (filled circles, $n=11$ ) and oligo-mesotrophic lakes (open circles, $n=11$ ) to (a) $\mathrm{C}_{\text {phyto }}$ and (b) $p \mathrm{CO}_{2}$. Panel (c) presents a box whisker plot of calculated $\varepsilon \mathrm{CO}_{2}$-algae in eutrophic (Eu) and oligo-mesotrophic (Oli-Meso) lakes.

on species composition (summarized in, e.g., Hayes, 2001), growth conditions (e.g. Riebesell et al., 2000) and the FA considered (Fig. 5).

Isotope fractionation between $\mathrm{CO}_{2}$ and phytoplankton was variable $(8-25 \%$ ) in our study (Table 3 ). This implies that calculations of $\delta^{13} \mathrm{C}_{\text {phyto }}$ from $\delta^{13} \mathrm{C}_{\mathrm{CO}_{2}}$ with a constant fractionation factor provide inaccurate results, consistent with methodological comparisons by Marty and Planas (2008) and McCallister and del Giorgio (2008). The usual value for photosynthetic fractionation in phytoplankton is $\sim 20 \%$ o , based on $\mathrm{C}_{3}$ photosynthesis (Fry, 2006), but several studies that determined $\varepsilon$ in lakes showed that actual fractionation is usually lower than this value (Cole et al., 2002; Bade et al., 2006). Also, in our study, fractionation was lower $(\sim 17 \%$ ) on average, and highly variable, especially in eutrophic lakes. There are several explanations for this variability. Actual fractionation has been shown to be dependent on several variables, including growth rate (Bidigare et al., 1997) and $\mathrm{CO}_{2}$ availability (Laws et al., 1995). Fractionation is highest under high $\mathrm{CO}_{2}$ availability and low growth rates. In the less productive oligo-mesotrophic lakes, the conditions favour optimal fractionation, and therefore, fractionation was rather constant (Fig. 5c). In the productive, eutrophic lakes, actual fractionation was influenced by $p \mathrm{CO}_{2}$ and $\mathrm{C}_{\text {phyto }}$, with lowest fractionation and therefore most enriched ${ }^{13} \mathrm{C}$ phytoplankton in the most productive (low $\mathrm{CO}_{2}$ and high $\mathrm{C}_{\text {phyto }}$ ) lakes (Fig. 5a, b).

Two clusters in $\delta^{13} C_{\text {phyto }}$ were present in the eutrophic lakes (Fig. 5a, b) and the shift occurred when lakes were below $20 \mu \mathrm{mol} \mathrm{L}{ }^{-1} \mathrm{CO}_{2}$ in the eutrophic lakes. When $\mathrm{CO}_{2}$ becomes limiting, some phytoplankton can also shift to bicarbonate utilization, which is isotopically enriched by $\sim 8 \%$ o compared to $\mathrm{CO}_{2}$. Direct uptake of carbonate and conversion in the carboxysomes is very common in the cyanobacteria that dominate eutrophic lakes (Bontes et al., 2006). The lakes with ${ }^{13} \mathrm{C}$-enriched phytoplankton had high concentrations of zeaxanthin, a biomarker for cyanobacteria. However, the higher $\delta^{13} \mathrm{C}_{\text {phyto }}$ in high zeaxanthin lakes was not a direct consequence of ${ }^{13} \mathrm{C}$-enrichment in cyanobacteria. FA that are abundant in cyanobacteria $(18: n \omega n)$ were not more enriched than FA that are absent in cyanobacteria; in fact, they were the most ${ }^{13} \mathrm{C}$-depleted of all FA (Fig. 4). Cyanobacteria grown in laboratory cultures also showed higher fractionation (up to $9 \%$ ) in lipids relative to total biomass than eukaryotic phytoplankton (summarized in Hayes, 2001).

The most ${ }^{13} \mathrm{C}$-enriched phytoplankton FA was $22: 6 \omega 3$, which is abundant in dinoflagellates (Fig. 4) (Dalsgaard et al., 2003). Dinoflagellates were also more enriched in ${ }^{13} \mathrm{C}$ compared to other phytoplankton in a subtropical lake (Zohary et al., 1994). A possible explanation for ${ }^{13} \mathrm{C}$-enriched dinoflagellates in field studies, can be their mixotrophic character, so that part of their isotopic composition reflects consumer $\delta^{13} \mathrm{C}$. However, PUFAs of autotrophic dinoflagellates grown in continuous cultures were also more ${ }^{13} \mathrm{C}$-enriched to $\mathrm{C} 16: 0$ than PUFAs of other phytoplankton (Schouten et al., 1998).

Finally, variability in $\Delta \delta^{13} \mathrm{C}_{\mathrm{FA} \text {-cell }}$ can contribute to the observed variability. In laboratory studies, the offset between lipids and bulk material has been shown to be variable (van Dongen et al., 2002, Fiorini et al., 2010). One can expect that in field studies, with multiple species, however, these cellular variations would probably disappear within broader trends. If we assume an overall mean $\Delta \delta^{13} \mathrm{C}_{\mathrm{FA}-\text { cell }}$, then the uncertainty in the actual value would affect the absolute fractionation values, but not the observed variability in fractionation.

\subsection{Carbohydrates and lipid $\delta^{13} \mathrm{C}$}

The enrichment in ${ }^{13} \mathrm{C}$ of carbohydrates and depletion in ${ }^{13} \mathrm{C}$ of lipids relative to total cells (mainly amino acids) has been shown in culture studies of phytoplankton (Van Dongen et al., 2002) and of several primary producers and consumers (Teece and Fogel, 2007). Results of this study show that the enrichment in ${ }^{13} \mathrm{C}$ in glucose as well as the ${ }^{13} \mathrm{C}$-depletion in in fatty acids relative to bulk material can also be detected in field samples (Fig. 2, Table 3). We observed that $\Delta \delta^{13} \mathrm{C}_{\mathrm{gluc}}-\mathrm{FA}_{\mathrm{tot}}$ increased with TP (Table 2), but whether this represents a general phenomenon for lakes needs further exploration.

Bacterial FA were more enriched in ${ }^{13} \mathrm{C}$ than phytoplankton FA in all lakes (Figs. 2, 4). This observation can be explained by differences in carbon source or differences in $\Delta \delta^{13} \mathrm{C}_{\mathrm{FA}-\text { cell }}$ between phytoplankton and bacteria. 
Carbohydrates, present in high concentrations in DOC, form an important carbon source for bacteria. Since carbohydrates were the most ${ }^{13} \mathrm{C}$-enriched carbon source, a preferential use of carbohydrates would result in ${ }^{13} \mathrm{C}$-enriched bacteria (Fig. 2). Another explanation is that isotope fractionation during FA synthesis was smaller in bacteria compared to phytoplankton. There are no field studies on $\Delta \delta^{13} \mathrm{C}_{\mathrm{FA}-\text { cell }}$ in freshwater bacteria, but field studies on sediment and marine bacteria report a range of $0-5 \%$ in $\Delta \delta^{13} \mathrm{C}_{\mathrm{FA}-\text { cell }}$ (Hayes, 2001; Burke et al., 2003; Bouillon and Boschker, 2006). Burke et al. (2003) suggested that in field samples with complex communities and substrates, $\Delta \delta^{13} \mathrm{C}_{\mathrm{FA}-\text { cell }}$ would be $\sim 0 \%$. The results of our study support this idea, since bacterial FA had a similar $\delta^{13} \mathrm{C}$ as POC. If a similar $\Delta \delta^{13} \mathrm{C}_{\mathrm{FA} \text {-cell }}$ for phytoplankton and bacteria were used, bacteria would be more enriched in ${ }^{13} \mathrm{C}$ than its potential carbon sources in half of the studied lakes, which is rather unlikely.

\section{Conclusions}

Our results show that trophic state has a large influence on lake metabolism and carbon cycling in plankton food webs. Overall, eutrophic lakes had larger variability in $\delta^{13} \mathrm{C}$ in all organic carbon pools than oligo-mesotrophic lakes, caused by larger isotopic variability in the base of the food web in eutrophic lakes (both allochthonous and autochthonous carbon). In eutrophic lakes, $\delta^{13} \mathrm{C}_{\text {phyto }}$ showed that two clusters of phytoplankton were present, with the most ${ }^{13} \mathrm{C}$-enriched phytoplankton at high $\mathrm{CO}_{2}$ and high chl $a$. Dominance of cyanobacteria played a role, but enrichment in ${ }^{13} \mathrm{C}$ was present in all phytoplankton, as seen in specific PLFAs.

Acknowledgements. We gratefully acknowledge Kelly Poole, Amber Erickson, Dan Kendall and Josh McGinnis from the limnological laboratory, Iowa State University, for their assistance during sampling preparation, lake sampling and processing. We thank colleagues from the NIOZ Royal Netherlands Institute for Sea Research in Yerseke: Pieter van Rijswijk, Marco Houtekamer, Peter van Breugel, and Jurian Brasser for laboratory support and Karline Soetaert for analyses support. We thank Jan van Ooijen and Karel Bakker from NIOZ Texel for laboratory support. Two anonymous reviewers are acknowledged for their helpful comments. This work received financial support from Schure-Beijerinck-Popping (SBP) Fonds and from the Darwin Center for Biogeosciences supported by the Netherlands Organization of Scientific Research (NWO).

Edited by: S. Bouillon

\section{References}

Arbuckle, K. E. and Downing, J. A.: The influence of watershed land use on lake N: P in a predominantly agricultural landscape, Limnol. Oceanogr., 46, 970-975, 2001
Bade, D. L., Carpenter, S. R., Cole, J. J., Hanson, P. C., and Hesslein, R. H.: Controls of $\delta^{13} \mathrm{C}$-DIC in lakes: Geochemistry, lake metabolism, and morphometry, Limnol. Oceanogr., 49, 1160-72, 2004.

Bade, D. L., Pace, M. L., Cole, J. J., and Carpenter, S. R.: Can algal photosynthetic inorganic carbon isotope fractionation be predicted in lakes using existing models?, Aquat. Sci., 68, 142-153, 2006.

Bade, D. L., Carpenter, S. R., Cole, J. J., Pace, M. L., Kritzberg, E., Van de Bogert, M. C., Cory, R. M., and McKnight, D. M.: Sources and fates of dissolved organic carbon in lakes as determined by whole-lake carbon isotope additions, Biogeochemistry, 84, 115-129, 2007.

Bidigare, R. R., Fluegge, A., Freeman, K. H., Hanson, K. L., Hayes, J. M., Hollander, D., Jasper, J. P., King, L. L., Laws, E. A., Milder, J., Millero, F. J., Pancost, R., Popp, B. N., Steinberg, P. A., and Wakeham, S. G.: Consistent fractionation of ${ }^{13} \mathrm{C}$ in nature and in the laboratory: Growth-rate effects in some haptophyte algae, Glob. Biogeochem. Cy., 11, 279-292, 1997.

Bligh, E. G. and Dyer, W. J.: A rapid method of total lipid extraction and purification, Can. J. Biochem. Phys., 37, 911-917, 1959.

Bontes, B. M., Pel, R., Ibelings, B. W., Boschker, H. T. S., Middelburg, J. J., and Van Donk, E.: The effects of biomanipulation on the biogeochemistry, carbon isotopic composition and pelagic food web relations of a shallow lake, Biogeosciences, 3, 69-83, doi:10.5194/bg-3-69-2006, 2006.

Boschker, H. T. S. and Middelburg, J. J.: Stable isotopes and biomarkers in microbial ecology, FEMS Microbiol. Ecol., 40, 85-95, 2002.

Boschker, H. T. S., Moerdijk-Poortviiet, T. C. W., van Breugel, P., Houtekamer, M., and Middelburg, J. J.: A versatile method for stable carbon isotope analysis of carbohydrates by highperformance liquid chromatography/isotope ratio mass spectrometry, Rapid Commun. Mass Spectrom., 22, 3902-3908, doi:10.1002/rcm.3804, 2008.

Bouillon, S. and Boschker, H. T. S.: Bacterial carbon sources in coastal sediments: a cross-system analysis based on stable isotope data of biomarkers, Biogeosciences, 3, 175-185, doi:10.5194/bg-3-175-2006, 2006.

Burke, R. A., Molina, M., Cox, J. E., Osher, L. J., and Piccolo, M. C.: Stable carbon isotope ratio and composition of microbial fatty acids in tropical soils, J. Environ. Qual., 32, 198-206, 10.2134/jeq2003.1980, 2003.

Carlson, R. E.: A trophic state index for lakes, Limnol. Oceanogr., 22, 361-369, 1977.

Coffin, R. B., Fry, B., Peterson, B. J., and Wright, R. T.: Carbon isotopic compositions of estuarine bacteria, Limnol. Oceanogr., 34, 1305-1310, 1989.

Coffin, R. B., Velinsky, D., Devereux, R., Price, W., and Cifuentes, L.: Stable carbon isotope analysis of nucleic acids to trace sources of dissolved substrates used by estuarine bacteria, Appl. Environ. Microbiol., 56, 2012-2020, 1990.

Cole, J. J., Caraco, N. F., Kling, G. W., and Kratz, T. K.: Carbon dioxide supersaturation in the surface waters of lakes, Science, 265, 1568-1570, 1994.

Cole, J. J., Carpenter, S. R., Kitchell, J. F., and Pace, M. L.: Pathways of organic carbon utilization in small lakes: Results from a whole-lake ${ }^{13} \mathrm{C}$ addition and coupled model, Limnol. Oceanogr., 47, 1664-1675, 2002. 
Cole, J. J., Prairie, Y. T., Caraco, N. F., McDowell, W. H., Tranvik, L. J., Striegl, R. G., Duarte, C. M., Kortelainen, P., Downing, J. A., Middelburg, J. J., and Melack, J.: Plumbing the global carbon cycle: Integrating inland waters into the terrestrial carbon budget, Ecosystems, 10, 171-184, 2007.

Dalsgaard, J., St. John, M., Kattner, G., Muller-Navarra, D., and Hagen, W.: Fatty acid trophic markers in the pelagic marine environment, Adv. Mar. Biol., 46, Academic Press Ltd, London, 225-340, 2003.

De Kluijver, A.: Carbon flows in natural plankton communities in the Anthropocene, Thesis Utrecht University, 156 pp., 2012.

De Kluijver, A., Yu, J., Houtekamer, M., Middelburg, J. J., and Liu, Z.: Cyanobacteria as a carbon source for zooplankton in eutrophic Lake Taihu, China, measured by ${ }^{13} \mathrm{C}$ labeling and fatty acid biomarkers, Limnol. Oceanogr, 57, 1245-1254, 2012.

Del Giorgio, P. A. and Gasol, J. M.: Biomass distribution in freshwater plankton communities, Am. Nat., 146, 135-152, 1995.

Del Giorgio, P. A. and Peters, R. H.: Patterns in planktonic $P: R$ ratios in lakes: Influence of lake trophy and dissolved organic carbon, Limnol. Oceanogr., 39, 772-787, 1994.

Dijkman, N. A. and Kromkamp, J. C.: Phospholipid-derived fatty acids as chemotaxonomic markers for phytoplankton: application for inferring phytoplankton composition, Mar. Ecol.-Prog. Ser., 324, 113-125, 2006.

Fiorini, S., Gattuso, J.-P., van Rijswijk, P., and Middelburg, J.: Coccolithophores lipid and carbon isotope composition and their variability related to changes in seawater carbonate chemistry, J. Exp. Mar. Biol. Ecol., 394, 74-85, 2010.

Fry, B.: Stable isotope ecology, Springer, 2006.

Gillikin, D. P. and Bouillon, S.: Determination of $\delta^{18} \mathrm{O}$ of water and $\delta^{13} \mathrm{C}$ of dissolved inorganic carbon using a simple modification of an elemental analyser-isotope ratio mass spectrometer: an evaluation, Rapid Commun. Mass Spectrom., 21, 1475-1478, 2007.

Grimley, D. A.: Glacial and nonglacial sediment contributions to Wisconsin Episode loess in the central United States, Geol. Soc. Am. Bull., 112, 1475-1495, 2000.

Hanson, P. C., Bade, D. L., Carpenter, S. R., and Kratz, T. K.: Lake metabolism: Relationships with dissolved organic carbon and phosphorus, Limnol. Oceanogr., 48, 1112-1119, 2003.

Hayes, J. M.: Fractionation of carbon and hydrogen isotopes in biosynthetic processes, in: Stable Isotope Geochemistry, Reviews in Mineralogy \& Geochemistry, Mineralogical Soc. America, Washington, 225-277, 2001.

Herczeg, A.: A stable carbon isotope study of dissolved inorganic carbon cycling in a softwater lake, Biogeochemistry, 4, 231-263, doi:10.1007/BF02187369, 1987.

Herczeg, A. L. and Fairbanks, R. G.: Anomalous carbon isotope fractionation between atmospheric $\mathrm{CO}_{2}$ and dissolved inorganic carbon induced by intense photosynthesis, Geochim. Cosmochim. Ac., 51, 895-899, 1987.

Hofmann, A. F., Soetaert, K., Middelburg, J. J., and Meysman, F. J. R.: AquaEnv - an Aquatic acid-base modeling Environment in R, R-package version 1, 2010.

Jones, R. I., Grey, J., Sleep, D., and Arvola, L.: Stable isotope analysis of zooplankton carbon nutrition in humic lakes, Oikos, 97-104, 1999.
Kaneda, T.: Iso-fatty and anteiso-fatty acids in bacteria - biosynthesis, function, and taxonomic significance, Microbiol. Rev. 55, 288-302, 1991.

Kohn, M. J.: Carbon isotope compositions of terrestrial $\mathrm{C}_{3}$ plants as indicators of (paleo)ecology and (paleo)climate, Proc. Natl. Acad. Sci., 107, 19691-19695, doi:10.1073/pnas.1004933107, 2010.

Kritzberg, E. S., Cole, J. J., Pace, M. L., Granéli, W., and Bade, D. L.: Autochthonous versus allochthonous carbon sources of bacteria: Results from whole-lake ${ }^{13} \mathrm{C}$ addition experiments, Limnol. Oceanogr., 49, 588-596, 2004.

Laws, E. A., Popp, B. N., Bidigare, R. R., Kennicutt, M. C., and Macko, S. A.: Dependence of phytoplankton carbon isotopic composition on growth-rate and $\left[\mathrm{CO}_{2}\right](\mathrm{aq})$ - theoretical considerations and experimental results, Geochim. Cosmochim. Ac., 59, 1131-1138, 1995.

Lennon, J. T., Faiia, A. M., Feng, X. H., and Cottingham, K. L.: Relative importance of $\mathrm{CO}_{2}$ recycling and $\mathrm{CH}_{4}$ pathways in lake food webs along a dissolved organic carbon gradient, Limnol. Oceanogr., 51, 1602-1613, 2006.

Marty, J. and Planas, D.: Comparison of methods to determine algal $\delta^{13} \mathrm{C}$ in freshwater, Limnol. Oceanogr. Meth., 6, 51-63, 2008.

McCallister, S. L. and del Giorgio, P. A.: Direct measurement of the $\delta^{13} \mathrm{C}$ signature of carbon respired by bacteria in lakes: Linkages to potential carbon sources, ecosystem baseline metabolism, and $\mathrm{CO}_{2}$ fluxes, Limnol. Oceanogr., 53, 1204-1216, 2008.

McDonald, C. P., Stets, E. G., Striegl, R. G., and Butman, D.: Inorganic carbon loading as a primary driver of dissolved carbon dioxide concentrations in the lakes and reservoirs of the contiguous United States, Glob. Biogeochem. Cy., 27, 1-11, doi:10.1002/gbc.20032, 2013.

Middelburg, J. J.: Stable isotopes dissect aquatic food webs from the top to the bottom, Biogeosciences, 11, 2357-2371, doi:10.5194/bg-11-2357-2014, 2014.

Middelburg, J. J., Barranguet, C., Boschker, H. T. S., Herman, P. M. J., Moens, T., and Heip, C. H. R.: The fate of intertidal microphytobenthos carbon: An in situ ${ }^{13} \mathrm{C}$-labeling study, Limnol. Oceanogr., 45, 1224-1234, 2000.

Nieuwenhuize, J., Maas, Y. E. M., and Middelburg, J. J.: Rapid analysis of organic carbon and nitrogen in particulate materials, Mar. Chem., 45, 217-224, 1994.

Pace, M. L., Carpenter, S. R., Cole, J. J., Coloso, J. J., Kitchell, J. F., Hodgson, J. R., Middelburg, J. J., Preston, N. D., Solomon, C. T., and Weidel, B. C.: Does terrestrial organic carbon subsidize the planktonic food web in a clear-water lake?, Limnol. Oceanogr., 52, 2177-2189, 2007.

Parker, S., Poulson, S., Smith, M. G., Weyer, C., and Bates, K.: Temporal variability in the concentration and stable carbon isotope composition of dissolved inorganic and organic carbon in two Montana, USA rivers, Aquat. Geochem., 16, 61-84, doi:10.1007/s10498-009-9068-1, 2010.

Pel, R., Floris, V., and Hoogveld, H.: Analysis of planktonic community structure and trophic interactions using refined isotopic signatures determined by combining fluorescence-activated cell sorting and isotope-ratio mass spectrometry, Freshw. Biol., 49, 546-562, 2004.

Riebesell, U., Burkhardt, S., Dauelsberg, A., and Kroon, B.: Carbon isotope fractionation by a marine diatom: dependence on 
the growth-rate-limiting resource, Mar. Ecol.-Prog. Ser., 193, 295-303, 2000.

Schindler, D. E., Carpenter, S. R., Cole, J. J., Kitchell, J. F., and Pace, M. L.: Influence of food web structure on carbon exchange between lakes and the atmosphere, Science, 277, 248-251, 1997.

Schouten, S., Breteler, W., Blokker, P., Schogt, N., Rijpstra, W. I. C., Grice, K., Baas, M., and Damste, J. S. S.: Biosynthetic effects on the stable carbon isotopic compositions of algal lipids: Implications for deciphering the carbon isotopic biomarker record, Geochim. Cosmochim. Acta, 62, 1397-1406, 1998

Stoll, M., Bakker, K., Nobbe, G., and Haese, R.: Continuous-flow analysis of dissolved inorganic carbon content in seawater, Anal. Chem., 73, 4111-4116, 2001.

Taipale, S., Kankaala, P., Tiirola, M., and Jones, R. I.: Whole-lake dissolved inorganic $\mathrm{C}-13$ additions reveal seasonal shifts in zooplankton diet, Ecology, 89, 463-474, 2008.

Taipale, S., Strandberg, U., Peltomaa, E., Galloway, A. W., Ojala, A., and Brett, M. T.: Fatty acid composition as biomarkers of freshwater microalgae: analysis of 37 strains of microalgae in 22 genera and in seven classes, Aquat. Microb. Ecol., 71, 165-178, 2013.

Teece, M. A. and Fogel, M. L.: Stable carbon isotope biogeochemistry of monosaccharides in aquatic organisms and terrestrial plants, Org. Geochem., 38, 458-473, doi:10.1016/j.orggeochem.2006.06.008, 2007.
Van den Meersche, K., Van Rijswijk, P., Soetaert, K., and Middelburg, J. J.: Autochthonous and allochthonous contributions to mesozooplankton diet in a tidal river and estuary: Integrating carbon isotope and fatty acid constraints, Limnol. Oceanogr, 54, 62-74, 2009.

van Dongen, B. E., Schouten, S., and Damste, J. S. S.: Carbon isotope variability in monosaccharides and lipids of aquatic algae and terrestrial plants, Mar. Ecol.-Prog. Ser., 232, 83-92, 2002.

Wilkinson, G. M., Pace, M. L., and Cole, J. J.: Terrestrial dominance of organic matter in north temperate lakes, Glob. Biogeochem. Cy., 27, 43-51, doi:10.1029/2012GB004453, 2013.

Wright, S. W.: Improved HPLC method for the analysis of chlorophylls and carotenoids from marine phytoplankton, Mar. Ecol.Prog. Ser., 77, 183-196, 1991.

Zhang, J., Quay, P. D., and Wilbur, D. O.: Carbon-isotope fractionation during gas-water exchange and dissolution of $\mathrm{CO}_{2}$, Geochim. Cosmochim. Ac., 59, 107-114, 1995.

Zigah, P. K., Minor, E. C., Werne, J. P., and Leigh McCallister, S.: An isotopic $\left(\Delta^{14} \mathrm{C}, \delta^{13} \mathrm{C}\right.$, and $\left.\delta^{15} \mathrm{~N}\right)$ investigation of the composition of particulate organic matter and zooplankton food sources in Lake Superior and across a size-gradient of aquatic systems, Biogeosciences, 9, 3663-3678, doi:10.5194/bg-9-36632012, 2012.

Zohary, T., Erez, J., Gophen, M., Bermanfrank, I., and Stiller, M.: Seasonality of stable carbon isotopes within the pegalic foodweb of lake Kinneret, Limnol. Oceanogr., 39, 1030-1043, 1994. 